\title{
Specimen sign
}

\author{
Mansoor Mehmood, Faisal A Khasawneh
}

Texas Tech University Health Sciences Center, Amarillo, Texas, USA

\section{Correspondence to}

Dr Faisal A Khasawneh, faisal.khasawneh@ttuhsc.edu

Accepted 3 May 2014

\section{(1) CrossMark}

To cite: Mehmood M, Khasawneh FA. BMJ Case Rep Published online: [please include Day Month Year] doi:10.1136/bcr-2013202850

\section{DESCRIPTION}

A 51-year-old man with no significant medical history presented to the infectious diseases clinic with a 5-month history of itching and crawling sensation under the skin. He claimed seeing some 'parasites' coming out of his skin at different spots. He had them collected in small boxes (figures 1 and 2). $\mathrm{He}$ denied alcohol or illicit drug use. Neither his wife nor kids had similar symptoms.

Physical examination showed excoriation marks but no evidence of pediculosis or scabies. Blood tests showed normal blood counts without eosinophilia, normal kidney and liver function tests and normal $C$ reactive protein value.

Based on the above clinical findings, he was diagnosed with delusional infestation (DI). After soliciting the help of his family, he was started on pimozide. Unfortunately, he was lost to follow-up after the third visit.

DI is characterised by patients' fixed belief that their skin and body is infested by small pathogens, although there is no medical or microbiological evidence for it. $^{1}$ Patients commonly collect

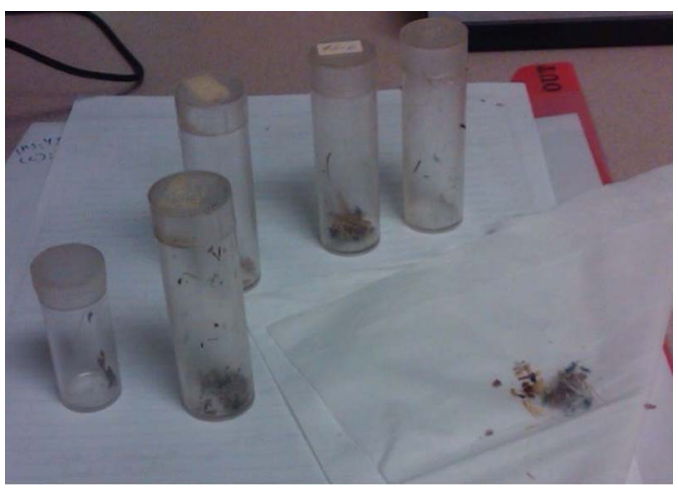

Figure 1 Small containers that have alleged parasites collected by the patient.

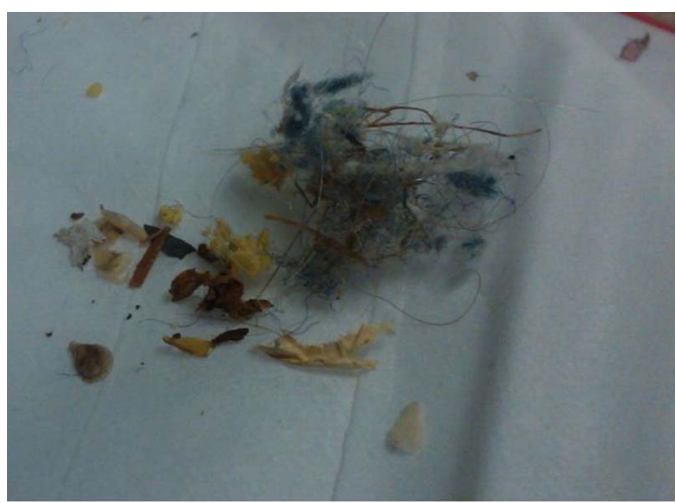

Figure 2 Close up picture of the collected samples showing hair, cloth fibers, seeds and dry weeds. samples of alleged pathogens in small containers, which is called 'matchbox' or 'specimen' sign. ${ }^{1}$ The illness has two forms: primary, which is a monosymptomatic delusional disorder, and secondary. ${ }^{1}$ The latter form is caused by an underlying illness or intoxication. Examples of secondary causes of DI include: psychiatric illnesses such as schizophrenia, organic brain disorders like dementia or brain tumours, substance abuse including cocaine, alcohol and methamphetamine, prescription medications, and general medical illnesses with pruritus and paraesthesia like lymphoma, polycythaemia, hyperbilirubinemia and xeroderma. ${ }^{2}{ }^{3}$

\section{Learning points}

- Delusional infestation (DI), delusional parasitosis in this case, is characterised by patients' fixed belief that their skin and body is infested by small pathogens, although there is no medical or microbiological evidence for it.

- Thorough history taking including travel and illicit drug use, and physical examination followed by appropriate blood testing, imaging studies and possibly skin biopsy are essential in ruling out true infestation and in identifying secondary causes of DI.

- Primary cases of DI are difficult to treat and their lack of insight leads to a high loss to follow-up rates. Principles of therapy include: acknowledge patient's suffering and show empathy, do not perform unnecessary testing or prescribe anti-infective agents without an indication, do not try to question the patient's beliefs and gradually try to introduce antipsychotics as helpful agents against the patient's distress and itching.

Contributors MM and FAK made the diagnosis, reviewed the literature and wrote the manuscript.

\section{Competing interests None.}

Patient consent Obtained.

Provenance and peer review Not commissioned; externally peer reviewed.

\section{REFERENCES}

1 Freudenmann RW, Lepping P. Delusional infestation. Clin Microbiol Rev 2009:22:690-732.

2 Swick BL, Walling HW. Drug-induced delusions of parasitosis during treatment of Parkinson's disease. J Am Acad Dermatol 2005;53:1086-7

3 Hinkle NC. Delusory parasitosis. Am Entomol 2000;46:17-25. 


\section{Images in...}

Copyright 2014 BMJ Publishing Group. All rights reserved. For permission to reuse any of this content visit http://group.bmj.com/group/rights-licensing/permissions.

BMJ Case Report Fellows may re-use this article for personal use and teaching without any further permission.

Become a Fellow of BMJ Case Reports today and you can:

- Submit as many cases as you like

- Enjoy fast sympathetic peer review and rapid publication of accepted articles

- Access all the published articles

- Re-use any of the published material for personal use and teaching without further permission

For information on Institutional Fellowships contact consortiasales@bmjgroup.com

Visit casereports.bmj.com for more articles like this and to become a Fellow 